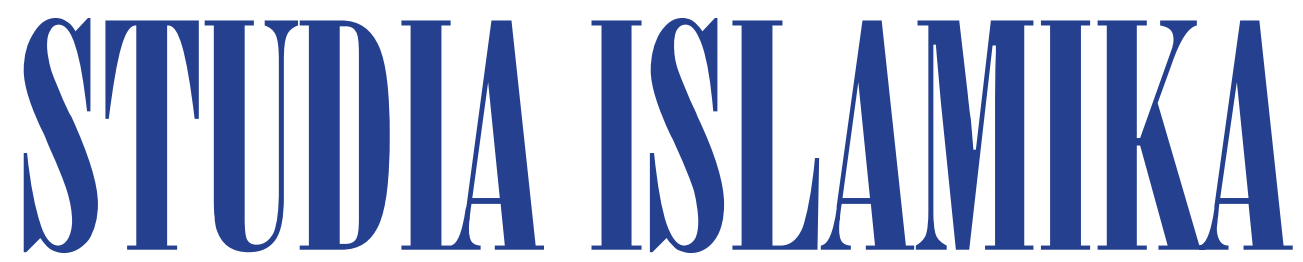

INDONESIAN JOURNAL FOR ISLAMIC STUDIES

Volume 20, Number 1, 2013

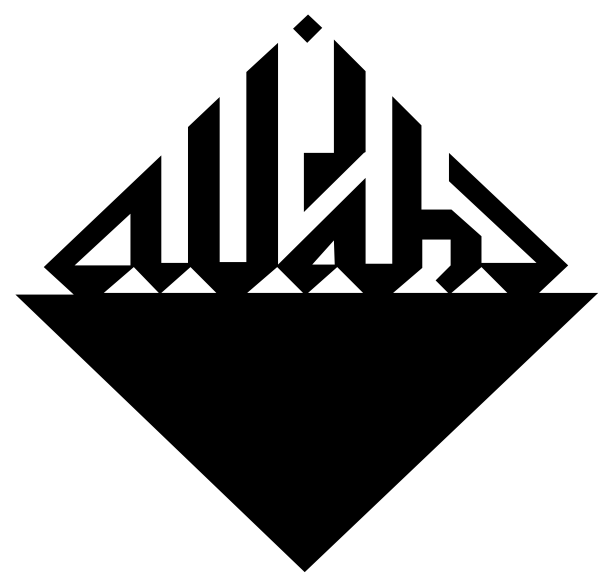

Buddhism in MusLim Indonesia

Karel Steenbrink

The Missing Minister of Religion and the PSII:

A Contextual Biography of K.H. Ahmad Azhary

Kevin W. Fogg

KitaB BERLADANG: A Portrait of

Hybrid Islam in West Kalimantan

Faizal Amin 


\section{STIDIIA ISLAVIIKK}





\section{STIDIIA ISLAVIIKK}

Indonesian Journal for Islamic Studies

Vol. 20, no. 1, 2013

EDITORIAL BOARD:

M. Quraish Shihab (UIN Syarif Hidayatullah Jakarta)

Taufik Abdullah (LIPI Jakarta)

Nur A. Fadhil Lubis (IAIN Sumatra Utara)

M.C. Ricklefs (Australian National University, Canberra)

Martin van Bruinessen (Utrecht University)

John R. Bowen (Washington University, St. Louis)

M. Kamal Hasan (International Islamic University, Kuala Lumpur)

Virginia M. Hooker (Australian National University, Canberra)

\section{EDITOR-IN-CHIEF}

Azyumardi Azra

\section{EDITORS}

Saiful Mujani

Jamhari

Jajat Burhanudin

Oman Fathurahman

Fuad Jabali

Ali Munhanif

Saiful Umam

Ismatu Ropi

Dina Afrianty

\section{ASSISTANT TO THE EDITORS}

Testriono

Muhammad Nida' Fadlan

ENGLISH LANGUAGE ADVISOR

Melissa Crouch

Simon Gladman

ARABIC LANGUAGE ADVISOR

Nursamad

\section{COVER DESIGNER}

S. Prinka

STUDIA ISLAMIKA (ISSN 0215-0492) is a journal published by the Center for the Study of Islam and Society (PPIM) UIN Syarif Hidayatullah, Jakarta (STT DEPPEN No. 129/SK/DITJEN/PPG/ STT/1976). It specializes in Indonesian Islamic studies in particular, and South-east Asian Islamic Studies in general, and is intended to communicate original researches and current issues on the subject. This journal warmly welcomes contributions from scholars of related disciplines.

All articles published do not necessarily represent the views of the journal, or other institutions to which it is affiliated. They are solely the views of the authors. The articles contained in this journal have been refereed by the Board of Editors.

STUDIA ISLAMIKA has been accredited by The Ministry of National Education, Republic of Indonesia as an academic journal (SK Dirjen Dikti No. 56/DIKTI/Kep/2012). 
(C) Copyright Reserved

Editorial Office:

STUDIA ISLAMIKA, Gedung Pusat Pengkajian

Islam dan Masyarakat (PPIM) UIN Jakarta,

Jl. Kertamukti No. 5, Pisangan Barat, Cirendeu,

Ciputat 15419, Jakarta, Indonesia.

Phone: (62-21) 7423543, 7499272, Fax: (62-21) 7408633;

E-mail: studia.islamika@uinjkt.ac.id

Website: studia.ppim.or.id

Annual subscription rates from outside Indonesia, institution: US\$75,00 and the cost of a single copy is US\$ 25,00; individual: US $\$ 50,00$ and the cost of a single copy is US\$20,00. Rates do not include international postage and handling.

Please make all payment through bank transfer to:

PPIM, Bank Mandiri KCP Tangerang Graha Karno's, Indonesia, account No. 101-00-0514550-1 (USD), Swift Code: bmriidja

Harga berlangganan di Indonesia untuk satu tahun, lembaga: Rp. 150.000,-, harga satu edisi Rp. 50.000,-; individu: Rp. 100.000,-, harga satu edisi Rp. 40.000,-. Harga belum termasuk ongkos kirim. 


\section{Table of Contents}

\section{Articles}

$1 \quad$ Karel Steenbrink

Buddhism in Muslim Indonesia

35 Kevin W. Fogg

The Missing Minister of Religion and the PSII:

A Contextual Biography of K.H. Ahmad Azhary

59 Faizal Amin

Kitab Berladang: A Portrait of Hybrid Islam in West Kalimantan

97 Iin Suryaningsib

Al-Haqiqqah al-Muwāfaqah li al-Sharīab:

al-Tașāluh bayn al-Tașawuf wa al-Sharī'ah

bi Nusantara fi al-Qarn al-Sādis 'Ashr al-Mīlādī

129 Tasman

Jadwal A'māl al-Ahyzāb al-Islāmīyah fī Indonesia

al-Mu'āṣirah: Bayn al-Sharīáh wa al-Dīmūqratīyah

\section{Book Review}

169 Azyumardi Azra

Islamisasi Jawa

\section{Document}

179 Oman Fathurahman

A Textual Approach to Understanding Nusantara Muslims 
Kevin W. Fogg

\title{
The Missing Minister of Religion and the PSII: A Contextual Biography of K. H. Ahmad Azhary
}

\begin{abstract}
This article provides a contextual biography of K.H. Ahmad Azhary, who was appointed as the Minister of Religion in the first Amir Sjarifuddin cabinet of the Republic of Indonesia in 1947. The life of this man provides insight into Islamic activity in South Sumatra and its connections with the Middle East, as well as with the rest of Indonesia. Most importantly, the examination of Azhary's appointment to the Indonesian cabinet - to a position that he was never able to hold — shines light onto the circumstances of the exit of Partai Sarekat Islam Indonesia (PSII, Indonesian Islamic Union Party) from Masjumi. Contradictory evidence about the reasons for the exit as presented in PSII and Masjumi sources are evaluated in light of Azhary's appointment and inability to join the cabinet. The article finds that PSII's rhetoric about initiative from the provinces to split from Masjumi was probably based on truth.
\end{abstract}

Key words: K.H. Ahmad Azhary, the first Amir Sjarifuddin cabinet, Partai Sarekat Islam Indonesia (PSII), Masjumi, Minister of Religion. 
Abstrak: Artikel ini merupakan biografi kontekstual K.H. Ahmad Azhary, yang diangkat sebagai Menteri Agama Republik Indonesia dalam Kabinet Amir Sjarifuddin yang pertama pada tahun 1947. Kehidupan Azhary memberi wawasan tentang aktivitas Islam di Sumatera Selatan dan dalam hubungannya dengan Timur Tengah dan dengan seluruh Indonesia. Yang paling penting, pembahasan tentang pengangkatan Azhary ke dalam kabinet Indonesia—ke dalam sebuah posisi yang tidak pernah didudukinya-memberi penjelasan tentang situasi keluarnya Partai Sarekat Islam Indonesia (PSII) dari Masyumi. Bukti berbeda tentang alasan-alasan keluarnya yang dihadirkan dalam sumber-sumber PSII dan Masyumi telah dievaluasi dalam kaitan dengan diangkatnya Azhary dan ketidakmampuannya bergabung dalam kabinet, membuktikan bahwa retorika PSII tentang inisiatif dari provinsi-provinsi untuk memisabkan diri dari Masyumi agaknya didasarkan pada kebenaran.

Kata kunci: K.H. Ahmad Azhary, Kabinet Amir Sjarifuddin yang pertama, Partai Sarekat Islam Indonesia (PSII), Masyumi, Menteri Agama.

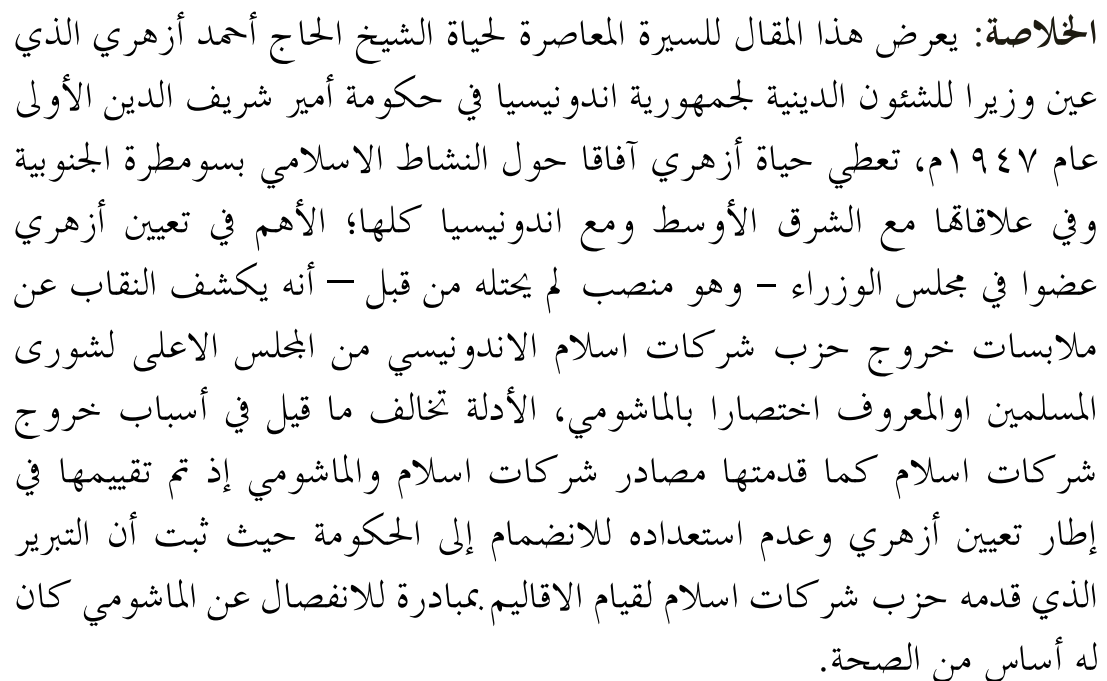

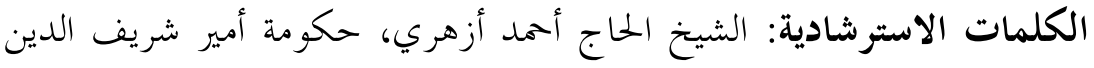

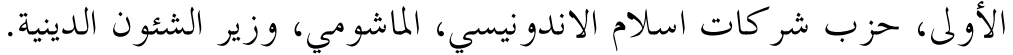


I $\mathrm{n}$ the landmark 1998 volume on Indonesia's ministers of religion, treating each former minister separately with his biography and key achievements while in office, no chapter covered the Minister of Religion from 1947-1948. ${ }^{1}$ This is because it is terribly difficult to determine who served as minister in this period. The man appointed was K.H. Ahmad Azhary, a leading religious scholar from Palembang, but he never assumed the post. This essay seeks to lay out his basic biographical information, the circumstances of his appointment, and why he did not hold the post to which he was appointed. This also provides an opportunity to broach some of the delicate history of Indonesian Islamic politics at the period of his appointment, in particular the split of the Partai Sarekat Islam Indonesia (PSII, Indonesian Islamic Union Party) ${ }^{2}$ from the umbrella Islamic party Masjumi. A contextual biography suggests the role that Azhary could have played in the fracture of Masjumi and how Azhary viewed the cabinet to which he was appointed, specifically whether he would have joined it had he been able.

\section{Early Life and Education}

K.H. Ahmad Azhary was born in Palembang, South Sumatra, around the turn of the 20th century. He himself was unable to name the exact date of his birth when asked on his membership form in the Constituent Assembly in 1956, so he wrote 'approximately 1900'. ${ }^{3} \mathrm{He}$ was the only son of a family of traders, including both his father, Abdul Hamid and his future father-in-law, Haji Akil, the latter of whom was a very prominent business interest in town. ${ }^{4}$ Haji Akil was the first native (non-European and non-Chinese) in Palembang to establish a private firm under Dutch law (Firma Haji Akil), and was instrumental in supporting the early steps of modern Islamic schools in the city. ${ }^{5}$

At that time, Islamic education in Palembang was growing fast. In 1890, the Dutch colonial administration recorded 230 Islamic teachers in Palembang, with some 4500 students. ${ }^{6}$ While that figure showed a marked increase since the mid $-19^{\text {th }}$ century, it was to grow even more with increasing local wealth, which facilitated the sending of students to Arabia for advanced studies. Both coming from and marrying into wealthy families, Ahmad Azhary was one of those who had access to the best Islamic education of the time. He was schooled first at a pesantren in Palembang, where he learned Arabic and studied the classic 
Southeast Asian Islamic texts (kitab kuning). ${ }^{7}$ At the age of 25 , he set out for Cairo, where he enrolled at Al-Azhar University - the center of Muslim learning at the time. This university also inspired the surname he adopted, demonstrating his connection to the place.

Azhary was part of a wave of Sumatran students to study in the Middle East in the 1920s. Their numbers buoyed by rising rubber prices that allowed their parents to pay for their education; there were about 200 Southeast Asian students in Cairo when he arrived, most of them from West Sumatra. ${ }^{8}$ Those from South Sumatra often preferred the holy city of Mecca, where they made up about one-fourth of the Southeast Asian quarter in 1931. ' There must have been at least a few other South Sumatrans who also chose Cairo for their education, though; there were several other al-Azhar graduates teaching in Palembang by the late 1920s, making Ahmad Azhary special, but not unique. ${ }^{10}$ Several of these other graduates even used the same epithet - 'Azhary' - as an adopted surname, but none of them were related to Ahmad. ${ }^{11}$

While in Cairo, Azhary was an active member of the Djama'ah alChairiah al-Talabijja al-Azhariah al-Djawiah (Welfare Association of 'Jawa' Students at the University of al-Azhar). ${ }^{12}$ This organization was founded in 1922 by Indonesian students in Cairo, and by 1925 had grown into a hub of social, theological, and political activity for its members. ${ }^{13}$ When Ahmad Azhary arrived in Cairo, the organization's president was Fathurrahman Kafrawi, a Javanese theology student and also a future minister of religion. ${ }^{14}$

Ahmad Azhary later listed himself as having become the head (ketua) of the Djama'ah al-Chairiah; this is very possible although hard to confirm through outside sources. ${ }^{15}$ What is clear is his participation in publishing the magazine Usaha Pemuda. This journal was one of four Southeast Asian journals to emerge in Cairo in the 1920s, but it differed from its two predecessors by being the first journal to write romanized Malay instead of Malay which used the Arabic script (jawi). ${ }^{16}$ The issues dealt with in this journal were reportedly similar to the previous Arabic-script periodicals by Indonesian students in town: "the perfect Islam of the golden age, modern education, progress and empowerment through study abroad". ${ }^{17}$

During his long stay in Egypt, Ahmad Azhary found it appropriate to take another local wife. He had already married in Palembang before 
leaving for the Arab world, but his first wife was prohibited by her father from accompanying him on his sojourn to the Middle East (foreshadowing another prohibition in the other direction a few years later). Following permissible practice in Islam, Azhary found a Cairene woman whom he married in the late 1920s, and together they had two sons. ${ }^{18}$

Theologically, Ahmad Azhary was a reformist, following the line of Muhammad 'Abduh in that the gates of interpretation could be reopened and Muslims could transcend the schools of jurisprudence. This was in line with the majority of his Southeast Asian colleagues at al-Azhar, and indeed with the general tenor of the university itself, where 'Abduh had been appointed to a leadership role at the beginning of the century. ${ }^{19}$ As his scholarly specialty, Ahmad Azhary took to the study of the traditions of the Prophet, coming out of the university as ahl al-hadith. ${ }^{20}$

Despite his orientation towards Islamic reformism, Azhary was not an activist in the main organization which upheld this theological position in Indonesia - Muhammadiyah. In this he differed from several of his Javanese colleagues from Cairo, including Fathurrahman Kafrawi, but fell within the tradition of many Sumatran students. ${ }^{21}$ Rather, both before leaving Sumatra and after his return, Ahmad Azhary functioned independently of organizations operating along theological lines, and instead he was inclined towards politics. ${ }^{22}$

\section{Return to Indonesia}

In 1932, after seven years' sojourn in Cairo, Ahmad Azhary returned to the Dutch East Indies. His Cairene wife was unable to join him, being prohibited from doing so by her father in a curious inverse of the experience of Azhary's first wife on his departure for Cairo. Thus, the second wife and her two sons remained in Egypt and lost contact with Azhary. ${ }^{23}$ His first wife and his extended family, though, awaited him in Palembang.

In 1934, probably using funding available from his father and inlaws as well as his reputation as a Middle East-trained scholar, Azhary founded his own school - Sekolah Rendah dan Menengah Islam alHidajatul Islamijah. This school fell within a broader movement of the reform of Islamic education in Palembang. As one local historian noted: "Efforts at the renewal of Islamic education in the Palembang region 
were based directly on ideas brought back by alumni of Islamic studies in the centers of Islamic studies in the Middle East." ${ }^{24}$ The organization of Azhary's school was modern, with class divisions and non-Islamic material included in the curriculum. This venture lasted until 1942, when the Japanese shut down all private schools in the city. ${ }^{25}$ Although Azhary would never teach at the school again following its closure, Muhammadiyah later revived it and integrated it into a new school within their system. ${ }^{26}$

Ahmad Azhary was modern in other ways beyond merely his theological and educational stance. He had a passive knowledge of English and Dutch, and felt equally comfortable in the Roman and Arabic scripts. ${ }^{27} \mathrm{He}$ was also a heavy smoker, coming to prefer the 'Kansas' brand cigarettes produced by British-American Tobacco. He would smoke up to 20 cigarettes a day by the 1950s, a habit that caught up with him towards the end of his life. ${ }^{28}$

A few years after his return to Palembang, Ahmad Azhary became involved in PSII, the leading Islamic political party of the day. ${ }^{29}$ This party had grown out of a mutual aid and trading group, Sarekat Islam (Islamic Union), founded in 1912. After some political evolution and the excise of its communist faction, this group became the Partai Sarekat Islam (Islamic Union Party) in 1923, and several years later in 1929 it adopted the PSII name and an explicitly religious-nationalist platform. ${ }^{30}$

Ahmad Azhary recorded his affiliation with the party to have started in 1937, when he listed himself as the leader of PSII for South Sumatra, but he must have been a member before this date. From this same year, Azhary listed himself as a member of the Central Committee (Dewan Pusat) of PSII, the highest governing board of the party. ${ }^{31}$ The nature of his relationship with PSII, which becomes crucial to his appointment as minister of religion in 1947, is important but poorly documented. Azhary lists his involvement in PSII as ending in 1945, but the entire organization suspended operations in 1942 when the Japanese decreed a ban on all groups and public meetings. ${ }^{32}$ This means that from 1942 there would have been no guidance from the central leadership and no permitted activities, but most importantly there was likely no communication with other PSII branches around the country. The Japanese occupation was, by most accounts, a time of almost no political or organizational activity in South Sumatra. ${ }^{33}$ The next flurry of activity came during the Revolution. 


\section{The Revolution and the Rebirth of PSII}

To properly contextualize Ahmad Azhary's appointment as minister of religion in the fourth revolutionary cabinet, it is necessary to say a few words about the Revolution in general, the evolution of Islamic politics, and the rebirth of the PSII. Although the proclamation of Indonesia's independence in August 1945 marked a major change for general governmental issues, the administration of religion from the Japanese era to the newly independent Republic saw much more continuity. The Japanese had elevated several leading figures from the Muhammadiyah and Nahdlatul Ulama (NU) organizations (the major reformist and traditionalist organizations on Java, respectively) to positions of governmental leadership, and increasingly paid attention to the administration of religious (especially Islamic) issues. ${ }^{34}$ This paved the way for Islamic issues to take a larger and more prominent place in the Indonesian government, including with the creation of a Ministry of Religion in early 1946. ${ }^{35}$ The ministry was a decisive step for the Muslim community, because for the first time all manner of religious issues (pilgrimage, marriage registration, support of religious schools, mosque construction, religious publications, Islamic courts, etc.) were brought under the same roof.

Another decisive step for the Islamic community at the time was the creation of a unitary and national Islamic party called Masjumi. This political party, built from but not identical to a social organization of the same name under the Japanese, was the first time that Muslims held a united political front, which was especially important after great fracturing of the Islamic nationalist movement in the late 1930s. ${ }^{36}$ Masjumi conceived of itself as all-encompassing, covering the entire archipelago and serving as the sole political vehicle for Muslim interests. In practice, however, this vision could not easily be achieved under the conditions of the Revolution. Especially outside of Java, where it had not existed as a social organization under the Japanese and therefore was less widely known, Masjumi's sway was quite limited, and some parts of the archipelago had still never heard about the party by the time when the Revolution was drawing to a close. ${ }^{37}$ Still, in national politics Masjumi was recognized from 1945 until 1947 as the only political vehicle for Islamic interests. ${ }^{38}$

This unity, a point of great initial pride in the Islamic community, was broken in 1947 when the PSII, harkening back to its heritage 
as an independent group in the Dutch colonial era, exited Masjumi (or, according to some accounts, re-activated a structure that had always been independent). The rebirth of PSII as a separate party is not a subject that later PSII documents often treat; in fact, it is very often conspicuously skipped over. For example, none of the recorded messages of the 1953 party congress in Jakarta, not even the historical article titled 40 Years of the PSII's Struggle, mention the rebirth, which had happened just over five years earlier. ${ }^{39}$

Those PSII documents that do talk about the re-emergence of the party are inconsistent. In the year-by-year timeline published by the party in 1952, the party listed the initiative for its re-activation as coming from branches in Sulawesi and Sumatra in 1946, with W. Wondoamiseno taking the lead only because the party's chairman, Abikusno Tjokrosujoso, was in prison..$^{40}$ On the other hand, according to the account published by Wondoamiseno in 1948, the initiative to launch PSII as an active party again came from Sumatra (not Sulawesi), and it was answered with a declaration of Harsono Tjokroaminoto (not Wondoamiseno) in 1947 that ended the period of suspended activity. ${ }^{41}$ Harsono Tjokroaminoto himself dated the re-activation of the party to 1948 in a lengthy oral history interview, and he made no mention of initiative from the outer islands. ${ }^{42}$ Among outsider accounts, the most reliable is probably that of George Kahin, who was in Yogyakarta the acting Indonesian capital at the time - and was in close contact with Indonesian leaders of all stripes. Kahin reported a conversation with Abikusno Tjokrosujoso, who claimed the PSII "was re-established in July 1947, against his express wishes, by Wondoamiseno and Arudji Kartawinata as a result of a deal between them and [Amir] Sjarifuddin, who needed Islamic political backing for the cabinet he was attempting to form, the Masjumi having refused to support him". ${ }^{43}$ This latter account, focused on 'political opportunism', is now the standard historical narrative, although it has been consistently challenged by PSII documents and individuals. ${ }^{44}$

The aforementioned deal between Amir Sjarifuddin and certain PSII politicians was to create a cabinet under Amir's leadership. The creation of this cabinet should be placed in proper context to show the changing relationship of Masjumi to state power. The first few cabinets of independent Indonesia had been led by another socialist, Sutan Sjahrir, who had several strong connections with Islamic politicians, including 
in Masjumi. ${ }^{45}$ Thus, Masjumi men were willing, often enthusiastic, to serve in Sjahrir's cabinets, including H. Rasjidi and Fathurrahman Kafrawi, who had served as the first two ministers of religion.

When Sjahrir's second cabinet fell, four were appointed to the new cabinet: Amir Sjarifuddin (from the Socialist Party), Sukiman (Masjumi), A.K. Gani (Indonesian Nationalist Party) and Setiadjit (Labor Party). Sukiman felt his negotiating position was strong, but he might have overplayed his hand. When he demanded all of the position of prime minister, defence minister, foreign affairs minister and home affairs minister for his own party, negotiations failed and Sukiman was forced to leave the table. The remaining three went on to form a cabinet in July 1947 under the leadership of Amir, but they knew that they needed to find Islamic support for this cabinet to hold a popular mandate. ${ }^{46}$

Finding Islamic support for Amir's cabinet was a tricky proposition because of the large animosity he personally engendered in the Muslim community. Amir had been born to a Muslim family in Medan in 1907 but converted to Christianity at the age of 24, and collaborated with the Dutch in the late 1930s. ${ }^{47}$ This caused great distrust among Muslim leaders, and Amir's close affiliation with orthodox communists - who also came to hold a number of seats in his cabinet - did not help. ${ }^{48}$

After failed overtures to leading Masjumi members, Amir turned to some of the old men from PSII who had not yet won leading positions in the independent government to break the impasse. These men, most prominently W. Wondoamiseno and Arudji Kartawinata, had definitely held higher positions before the pre-war and Japanese eras, and were disappointed with their fate in the revolutionary Republic. However, it is not clear what other motivations might have been at play. With Wondoamiseno, he had been incarcerated through March 1947 in connection with an attempted coup in 1946; it is possible he had even been brought out of detention by Amir specifically to help re-launch PSII and bring it into the cabinet. ${ }^{49}$ According to the nowstandard 'political opportunism' narrative, these leaders re-launched the PSII with little or no popular support, and did so just to take up seats in the new cabinet.

PSII leaders offered an alternative narrative, which one might call the 'regional initiative' narrative. This story centers on a resolution sent from PSII leaders in Padang in late 1946, calling on the PSII 
to determine its stance in the new revolutionary environment. The resolution presented two basic options - either turning over PSII's assets to Masjumi so former members could support the new party, or (with some preference for the latter) to begin actively as PSII again. This resolution from Padang, West Sumatra, was co-signed by two leaders in South Sumatra (including K.H. Ahmad Azhary) and received by Wondoamiseno in April 1947. Wondoamiseno took the resolution as a solemn obligation to re-launch the PSII. ${ }^{50}$ This 'regional initiative' narrative thus presented the party as re-establishing itself several months before the fall of Sjahrir's cabinet, disallowing political expediency as the reason for the party's re-emergence. The veracity of this narrative hinges on the veracity of the resolution from Sumatra, later published by Wondoamiseno around 1948. The standard 'political opportunism' narrative rejected the possibility of real regional initiative, suggesting that there were no actual resolutions from the regions.

Both narratives agree on the outcome of the process, though: the new (or renewed) PSII was offered seven seats in the cabinet. Two of the appointees turned down their appointments, leaving the PSII with five seats. ${ }^{51}$ These cabinet appointees were: W. Wondoamiseno as Minister for Home Affairs; Arudji Kartawinata as Vice-Minister of Defense; Sukoso Wirjosaputro as Vice-Minister of Social Affairs; Sjahbuddin Latif as Minister of Information; K.H. Ahmad Azhary as Minister of Religion. ${ }^{52}$ This represented a substantial footing in national politics, especially because these seats included Wondoamiseno's position as Minister for Home Affairs and Arudji's spot as Vice-Minister of Defense. Each of the first four individuals were reputed to have a role in the party's re-birth - Wondoamiseno and Arudji as the two who made the deal with Amir, Sukoso Wirjosaputro as the Second ViceChairman (after the aforementioned two) in the hastily assembled Emergency Governing Board of the party, and Sjahbuddin Latif as one of the two leaders who - along with Harsono Tjokroaminoto issued the proclamation formally reviving the party. ${ }^{53}$

\section{K.H. Ahmad Azhary during the Revolution and His Episode as Minister of Religion}

The key question in this biographical essay is whether K.H. Ahmad Azhary also participated in the revival of the PSII and whether he intended to join the cabinet. To answer this, one must start by 
reviewing Azhary's activity during the Indonesian revolution. When the Revolution broke out in 1945, it is clear that Ahmad Azhary strongly supported the cause of independence; however, his specific activities are difficult to document. His son reports that he encouraged and supported a local Hizbullah militia associated with Masjumi, which seems very likely given the similar activities of other ulama at the time. ${ }^{54}$ However, this does not necessarily tie him strongly to Masjumi; the central party's control over Islamic militias in the regions was notoriously weak. ${ }^{55}$

The ostensible reason that Ahmad Azhary did not join the Amir cabinet was that he had been arrested by the Dutch, although it is unclear whether that happened before or after his appointment. Ahmad Azhary's son recalls vividly the image of his father's arrest by the Dutch, but not the exact timing of it. Nor does he remember how news came to Ahmad Azhary about his appointment to the cabinet in 1947. It is clear, however, that the Dutch held him well into 1948, to be released only for his mother's funeral. In the last year of the Revolution, Azhary and his family fled all the way to Lubuk Linggau, a small village well into the Bukit Barisan mountain range in the northwest corner of South Sumatra province. He returned as far as Muara Enim, where he was arrested and held by the Dutch for a second time. ${ }^{56}$

Despite a lack of details about the appointment, no one disputes that Azhary was appointed to the minister's post by the PSII. The appointment made sense from several other standpoints. Azhary came from Palembang, so he would be a representative of the outer islands in the cabinet. Furthermore, he fitted into the mould of other ministers of religion from the early Republic: graduate of al-Azhar; oriented towards modernity in administration; connected with Indonesian politics. ${ }^{57}$

Because Ahmad Azhary was never able to take up his post, Amir appointed a minister of religion ad interim to run the ministry in his absence. This individual, Anwaroeddin, is even less well documented than Ahmad Azhary - but that remains a project to be taken up by future scholars. On November 11, 1947, after a mere four months, Prime Minister Amir Sjarifuddin re-shuffled his cabinet, leading to the appointment of several Masjumi ministers to the cabinet. At that time, the NU-affiliated K.H. Masjkoer was appointed to replace Ahmad Azhary as minister, thus ending the latter's brief tenure as an official although not actual - member of the Indonesian cabinet. ${ }^{58}$ 
There are three possible interpretations regarding Ahmad Azhary's position in relation to PSII, Masjumi and the cabinet, and it is worth laying out all three here for the sake of argument. The first is that Ahmad Azhary strongly supported PSII through the end of the Revolution, intended to join the party as it was re-launched in 1947, conscientiously was ready to break with Masjumi as an umbrella Islamic party, and would have taken up his post in the cabinet had he not been captured by the Dutch. If this was so, then it is likely that the resolution from Sumatra that included his signature of support calling for PSII to be re-born was a genuine document and reflected his sentiment. The greatest problem with this interpretation is the later activities of Ahmad Azhary (detailed below) that show a consistent loyalty to Masjumi. If he had been devoted to PSII throughout the Revolution, why would he have changed this stance only in 1950 ?

The second possible interpretation is that Ahmad Azhary was loyal to Masjumi from its founding in 1945 and never intended to participate in separate PSII activities after 1942. If this was true, then the resolution published by Wondoamiseno to document support from the Sumatra branches for the rebirth of PSII would be fake, or at the very least Wondoamiseno would have spuriously added the name of Ahmad Azhary to them. If this were the case, then it is likely that Ahmad Azhary would not have joined the Amir Sjarifuddin cabinet even if he had been free and able to travel to Java, and the Dutch capture was either entirely coincidental with his appointment (perhaps a bit late, after his appointment was announced and his name had been passed along the Dutch command), or was not a real deterrent for Azhary to travel to Java and join the cabinet. This interpretation also implies that the 'regional initiative' narrative was false, created as a cover for the leaders' actual political opportunism.

The information form Ahmad Azhary filled out for the Constituent Assembly and the account of his son Tahir Azhary provides some facts that would support this narrative, but does not provide enough particulars or consistency to support it unequivocally. ${ }^{59}$ The other great question that arises from this interpretation comes from the perspective of Wondoamiseno and other PSII leaders who put forward Ahmad Azhary's name for Amir Sjarifuddin's cabinet: why would these PSII leaders suggest Azhary, despite his other qualifications, if they were not sure he would pass the litmus test of loyalty to their newly reassembled 
party? This suggests that there had been at least some contact between the PSII and Ahmad Azhary that led them to believe he supported their cause.

This, then, leads to the third interpretation, which in its general outline is probably closest to what actually happened. Ahmad Azhary may have joined in signing the resolution from Padang with the idea that the PSII might chose to formally fold itself into Masjumi, turning over its assets and encouraging its members to pursue the struggle through this new vehicle. ${ }^{60}$ Ahmad Azhary could just have easily supported PSII standing on its own again, as a growing divide appeared within the Islamic political community on certain policy issues. In either case, this allows for the possibility that the document presented by Wondoamiseno was genuine. This line of thinking also suggests that it was indeed only capture by the Dutch that prevented Ahmad Azhary from taking up his post in the cabinet, and that some time after his capture Azhary learned of the position of Masjumi and decided to stay loyal to the unitary party rather than join the PSII splinter party. Thus, coming into the 1950s Azhary was able to become a leader in Masjumi.

This last interpretation, involving initial loyalty to PSII as a potential subsidiary of Masjumi and a later turn to the unitary party once the two had split, is the most plausible of the three. It also presents a possible explanation for Ahmad Azhary's unexpected prominence in Masjumi during the 1950s — perhaps his high positions were in part a reward for his loyalty to Masjumi in the face of potential prominence in a rival party. Still, the structure of the resolution in question presented submission as an auxiliary of Masjumi as the less desirable option; one can see this in the repeated emphasis throughout that the party cannot simply disband.

Although none of these interpretations is impregnable and the exact nature of Ahmad Azhary's thinking is now impossible to know, the third and likeliest interpretation does suggest one important conclusion for the history of PSII that bears discussion. Careful examination of the appointment of Ahmad Azhary suggests that the resolution Wondoamiseno published around 1948 may very well have been genuine. This document, then, might have represented a genuine sentiment from former activists on Sumatra (and possibly Sulawesi) in favor of re-activating the PSII. However, this does not mean that the activists necessarily sought to splinter Masjumi; it is not clear 
how much information about Masjumi's unitary nature and role in central politics was available beyond Java. Assuming these documents were genuine, though, in some ways redeems Wondoamiseno and his colleagues who led PSII to break out of Masjumi in 1947. Even if the letter was used merely as a fig leaf for an action they would have undertaken anyway, still one can conclude that there was popular sentiment in some regions at least in support of the move. To put it another way, the split of PSII must have involved at least some 'regional initiative' in addition to any 'political opportunism', despite the implications of some later authors. ${ }^{61}$

The last major source to use when evaluating these narratives is the oral history that Harsono Tjokroaminoto gave to researchers from the Indonesian National Archives 35 years later. In that account, Harsono claims that the PSII only re-activated in 1948 at a major conference in which Harsono himself was named as the president of the party. ${ }^{62}$ This suggests that whatever happened in 1947, the PSII moving forward was not proud of the way it had been re-activated, and so in the long run party leaders chose to emphasize a later date and wider participation as the key factors in the party's re-birth.

\section{Ahmad Azhary's Life after 1950}

After the Revolution, documentation about Ahmad Azhary's activities became considerably fuller, although he was never to reach the heights of the Indonesian cabinet again. He moved to Jakarta in 1949 to join national politics full time, and continued to live there for the final 20 years of his life, with the exception of a brief time living in Bandung as a member of the Constituent Assembly. ${ }^{63}$

Ahmad Azhary's most prominent roles in independent Indonesia were as a member of the Madjelis Sjuro (Consultative Council, the council of religious scholars guiding party policy) of Masjumi from 1951. He also served as a member of parliament from that time through the dissolution of Masjumi in 1960. ${ }^{64}$ In Parliament, Azhary was a member of the education section, pulling from his own experience of running a school and studying abroad. ${ }^{65}$ From December 1954, according to his own account, Azhary became the head of Masjumi's Madjelis Sjuro, making him in some ways the leading clergyman in the organization. ${ }^{66}$ As a representative of the Madjelis Sjuro, Azhary also sat on the central leadership from the party, starting in $1951 .{ }^{67}$ Finally, 
Azhary was elected a member of the Constituent Assembly, the body tasked with drafting Indonesia's new constitution, in $1955 .{ }^{68}$

One could ask why Ahmad Azhary, who was not a particularly wellpublished scholar and who did not have a large personal following from his home region or from across the country, was elevated to become the head of Masjumi's Madjelis Sjuro in the mid-1950s. The likely answer is that he constituted a compromise candidate between several different interests in the party. Theologically, he was a reformist, like the followers of Muhammadiyah, who made up the largest bloc in the party after the exit of NU. Organizationally, however, because he did not belong to Muhammadiyah, those members who also did not belong to Muhammadiyah or who supported smaller regional organizations probably would have supported his candidacy so as to prevent a Muhammadiyah monopoly on the party's structure. Additionally, as noted when considering his appointment as minister of religion, Azhary would have been able to represent the region of South Sumatra among the leadership, and so bring greater regional diversity, also, his educational credentials from al-Azhar were highly regarded. One can only speculate as to whether other party leaders also supported Azhary for leadership of the Madjelis Sjuro in part to thank him for his loyalty to Masjumi even when PSII had split off and offered him a cabinet position; on this possibility, the extant accounts are silent.

Ahmad Azhary was also on the committee that drafted a proposed constitution for Masjumi in 1955, laying out Masjumi's ideals if it achieved the goal of an Islamic state. ${ }^{69}$ This demonstrates Azhary's support of the basic party platform in favor of establishing Islam as the basis of the Indonesian state and using the principles (or possibly even the details) of Islamic law to formulate national law. Azhary voted with this bloc in the Constituent Assembly and must have supported the integration of the Jakarta Charter in Indonesia's constitution. ${ }^{70}$

Another issue on which Ahmad Azhary joined the majority in Masjumi was his staunch opposition to communism. Sitting on the Madjelis Sjuro in Masjumi, Azhary joined the juridical decision (fatwa) made by the party that the Indonesian Communist Party (PKI) was prohibited under Islamic law, ostensibly for being an atheist organization, and that Muslims were forbidden from supporting that party. ${ }^{71}$ This was a theme that he would repeat in the 1960 s, echoing national politics of that era. ${ }^{72}$ 
Other than his position in parliament, Masjumi's internal structure, and in the Constituent Assembly, Ahmad Azhary's name does not appear prominently in Indonesian political documents from the 1950s. He did not sponsor any major legislative initiatives, nor was he appointed to executive branch positions in the Indonesian Government again. Thus, his political career ended with the dissolution of Masjumi by presidential decree in $1960 .^{73}$

His role in public life did not end in 1960, however. In 1959, after the Constituent Assembly was disbanded by President Sukarno, Azhary began to teach at Ibn Khaldun University in Jakarta, which was conveniently located near his home. He also continued to act as an Islamic leader for his local community, providing fatwa to those who asked for them and leading religious ceremonies as appropriate. One of the fatwa he produced was, in fact, to proclaim tobacco products prohibited for Muslims, because of their effects on the body and the mind (through addiction). ${ }^{74}$ In the end, tobacco did contribute to his poor health in the 1960s, although the direct cause of Ahmad Azhary's eventual passing in February 1969 was pneumonia. He left behind two daughters and a son from his first (Indonesian) wife, and two sons by his second (Cairene) wife, many of whom were also active in Islamic life and continued to be so up until today. ${ }^{75}$

\section{Conclusions}

K.H. Ahmad Azhary (1900-1969) was a leader in the Indonesian community in Cairo in the 1920s, in the Islamic community of Palembang in the 1930s, in national Islamic politics in the 1940s and 1950s, and in the Islamic community of Jakarta in the 1960s. His story also sheds light on a critical moment in Indonesian national party politics: the first formal fracture of Masjumi through the separation of PSII.

The conclusions one can draw from information and speculation about Ahmad Azhary suggest that there was genuine regional support for the re-activation of PSII, and that Azhary may initially have been a part of it. Absolute certainty on these issues remains difficult to achieve, however, and so historians may never be able to state authoritatively the balance of interests that went into the splinter of Islamic politics in revolutionary Indonesia. 


\section{Endnotes}

1. Azyumardi Azra \& Saiful Umam (eds.), 1998. Menteri-Menteri Agama RI: Biografi Sosial-Politik (Jakarta: INIS, PPIM and Departemen Agama RI).

2. There are a plethora of ways to spell the second word in this party's name, including Sarekat, Serikat, and Sjarikat. Although the last is the most common in party materials from the 1950s, the first seems to be the scholarly consensus today, and is therefore the version that will appear in this article.

3. In Indonesian, 'kira2 th.1900'. Arsip Nasional Republik Indonesia (here after ANRI), Koleksi Konstituante RA9, \#10. Ahmad Azhary filled out this form in his own hand, and so it is a reliable source of self-provided information. His son in an interview listed Ahmad Azhary's date of birth as exactly 1900, but with the information from the father's form we can recognize this as an approximation. Interview with Tahir Azhary, Ciputat, January 17, 2010.

4. Interview with Tahir Azhary, Ciputat, August 22, 2012. Prof. Dr. H. M. Tahir Azhary (born 1939) is one of Ahmad Azhary's sons from his first wife, and later became a prominent professor of law at the University of Indonesia. He gave several interviews between 2010 and 2012 for this article, although on a few points the archival research contradicts his recollection. In the majority of the story, though, the oral history and extant documents mutually reinforce each other.

5. Interview with Tahir Azhary, Ciputat, August 22, 2012. See also Ismail, 2004. Madrasah dan Sekolah Islam di Karesidenan Palembang: 1925-1942, Sejarah Sosial Pendidikan Islam pada Masa Kolonial, Disertasi S3, UIN-Syarif Hidayatullah, Jakarta, 2004.

6. Jeroen Peeters, 1997. Kaum Tuo-Kaum Mudo: Perubahan Religius di Palembang, 18211942, Jakarta: INIS, p. 22.

7. Interview with Tahir Azhary, Ciputat, August 22, 2012.

8. William R. Roff, 1970. 'Indonesian and Malay Students in Cairo in the 1920s', in Indonesia vol. 9: p. 74.

9. Peeters, p. 154.

10. On the preference of South Sumatrans to study in Mecca and their prodigious numbers there in the 1920s and 1930s, see Ismail, pp. 279-284.

11. Other Islamic teachers in Palembang using variants on the name Azhary included K.H. Masjhoer Azhari (Ismail, 132) and Syekh Muhammad Azhary bin Abdullah al-Palembany (see Azim Amin, Abdul, 1998. Syekh Muhammad Azhary bin Abdullah al-Palembany dan Usahanya dalam Menegakkan Ajaran Agama Islam di Palembang Palembang: Pusat Penelitian IAIN Raden Fatah Palembang). Other graduates of alAzhar active in Palembang at the time included Muhammad H. Nanang Masrie (whose name 'Masrie' means 'of Egypt' instead of 'of Al-Azhar') and Hasan Basri Mohammad Amin. See Ismail, p139, p282. The fact that none of them were related to Ahmad Azhary was confirmed by the interview with Tahir Azhary, Ciputat, August 22, 2012.

12. This translation of the organization's name is from Roff, p. 73. The Indonesian on the form Ahmad Azhary filled out for the Konstituante was Perhimpunan Sosial Indonesia Al-Djamaijatul Choirijah, which would translate to "the Djamijatul Choirijah [Welfare Association] Indonesian Social Organization”. See ANRI, RA9 Konstituante, \#10. Laffan, Micahel Francis, 2003. Islamic Nationhood and Colonial Indonesia: The Umma below the Winds, New York: Routledge, p. 215 calls it 'The Welfare Association of Azhari Jawi Students'.

13. See Laffan, pp. 220-222.

14. Roff, p. 76.For more on Kafrawi, see Akh. Minhaji \& M. Atho Mudzhar, 'Prof. K.H. Fathurrahman Kafrawi: Pengajaran Agama di Sekolah Umum’ in Azyumardi Azra \& 
Saiful Umam, pp. 35-52; Laffan, pp. 215-222.

15. ANRI, Koleksi Konstituante RA9, \#10.

16. Tengkoe Jafizham, 1939. Studenten Indonesia di Mesir, Medan: Sinar Deli, p. 111. Roff, p. 86, n. 39, recognizes the existence of this journal, but has no further information on it besides the names of its editors, Abdullah Aidid and Ahmad Azhari.

17. Laffan, p. 222. Jafizham, p111 makes the point of Usaha Pemuda's similarity to other efforts.

18. Interview with Tahir Azhary, Ciputat, August 22, 2012.

19. See Schacht, J., 2012. 'Muhammad 'Abduh', in Encyclopedia of Islam, second edition, Leiden: Brill Online.

20. Interview with Tahir Azhary, Ciputat, August 22, 2012.

21. On the impact of reformist ideas and the late growth of Muhammadiyah in West Sumatra in the 1920s, see Kahin, Audrey, 1999. Rebellion to Integration: West Sumatra and the Indonesian Polity, Amsterdam: Amsterdam University Press, 53ff.

22. One local student from that era confirmed that in Palembang the division was generally three ways (PSII-NU-Muhammadiyah) rather than the usual two (NUMuhammadiyah), which must have made it easier for Ahmad Azhary to align himself only with the political group. Interview with Mochtar Effendy, Palembang, June 7, 2010.

23. Interview with Tahir Azhary, Ciputat, August 22, 2012. They re-established contact in the 1950s when Azhary joined a legislative junket to Egypt, and Azhary brought this wife and two sons to Indonesia permanently in the 1960s. The two children resulting from this marriage made their careers in the Arabic language section of Radio Republik Indonesia.

24. Ismail, p. 279.

25. On the Japanese shutting down all private, and particularly Islamic, schools, see Yusnaini, 1998. Sejarah Perkembangan Pondok Pesantren Al-Ittifaqiah Inderalaya Sumatera Selatan, Skripsi S1, Fakultas Adab dan Humaniora, IAIN-Raden Fatah, Palembang, p 31. Many other undergraduate theses from IAIN-Raden Fatah describe local Islamic schools being shut down by the Japanese upon their arrival, with schools re-opening or new schools being established in the late 1940s or early 1950s, around the time Ahmad Azhary was leaving Palembang. Mochtar Effendy, who was enrolled in school at this time, reports that all Muhammadiyah and PSII schools were shut down, but some NU teachers were still allowed to receive students in their own buildings. Interview with Mochtar Effendy, June 7, 2010, Palembang. This was confirmed by an NU activist from the era, K.H. Zen Syukri. Interview with K.H. Zen Syukri, Palembang, June 7, 2010.

26. Interview with Tahir Azhary, Ciputat, August 22, 2012.

27. Interview with Tahir Azhary, Ciputat, August 22, 2012.

28. Interview with Tahir Azhary, Ciputat, January 17, 2010.

29. For more on PSII during the colonial period, the party produced a year-byyear chronology in 1952 as PSII dari Tahun ke Tahun (Jakarta?]: Departemen Penerangandan Propaganda PSII, [1952]). Also useful is the account available in Deliar Noer, 1973. The Modernist Muslim Movement in Indonesia, 1900-1942, Singapore: Oxford University Press.

30. The most lucid and concise account of these evolutions I have found is Robert Elson, 2009. 'Disunity, Distance, Disregard: The Political Failure of Islamism in Late Colonial Indonesia', in Studia Islamika, vol 16 no. 1.

31. ANRI, Koleksi Konstituante RA9, \#10.

32. PSII dari Tahun ke Tahun, p. 14. 
33. Interview with K.H. Zen Syukri, Palembang, June 7, 2010; interview with Mochtar Effendy, Palembang, June 7, 2010.

34. For an overview of the administration of Islam under the Japanese, see Henry J. Benda, 1958. The Crescent and the Rising Sun: Indonesian Islam under the Japanese Occupation, 1942-1945, The Hague: W. van Hoeve.

35. On the formation of the Ministry of Religion, see Kevin W. Fogg, 2012. The Fate of Muslim Nationalism in Independent Indonesia, PhD. Dissertation, Yale University, pp. 110-114.

36. On the history of Masjumi generally, see Deliar Noer, 1960. Masjumi: Its Organization, Ideology, and Political role in Indonesia, MA Thesis, Cornell University. On the fracturing of the Islamic political movement in the 1930s, see Elson, passim.

37. See, for example, the letter of K. Taufiqurachman in Jogjakarta to Husain Bin Aliein Tidore, North Maluku, dated October 10, 1949, explaining to him the existence of a Ministry of Religion in the new state and the position of Masjumi as an Islamic party. ANRI, Koleksi Sekretariat Negara 1945-1949 RA2, \#476.

38. On regional Islamic parties that emerged during the Revolution outside of Masjumi, see Fogg, pp. 125-133. The most prominent of these regional parties was PersatuanTarbiyah Indonesia (Perti) in West Sumatra, but even Perti had no footing in national politics until the close of the revolution.

39. Kongres P.S.I.I. ke-29: 20-27 Maret 1953 di Jakarta, Jakarta: Partai Sjarikat Islam Indonesia, 1953.

40. PSII dari Tahun ke Tahun, p. 14.

41. Putjuk Pimpinan Partai Sjarikat Islam Indonesia, Bagian Penjiaran, Barisan Partai Sjarikat Islam Indonesia Bersiap!: Sedjarah Pembangunan P.S.I.I. Kembali ([Jogjakarta?]: Partai Sjarikat Islam Indonesia, [1948?]).

42. Oral History with Harsono Tjokroaminoto, 1982. Interview by Wardiningsih Surjohardjo, ANRI Koleksi Sejarah Lisan, 1982 \#60 tape 16.

43. George McTurman Kahin, 1952. Nationalism and Revolution in Indonesia, Ithaca, NY: Cornell University Press, p210. Note that Abikusno had very much changed his tune by the time of another interview with Kahin in Washington, DC, on November 7, 1949. In that interview, Abikusno claimed that PSII was looking to become a stronger party than the Masjumi, and both Muhammadiyah and NU were likely to leave Masjumi to join with PSII. Needless to say, this did not come to pass. See McTurnan Kahin, Papers, \#14-27-3146, Division of Rare and Manuscript Collections, Cornell University Library, Box 54, Folder 'PSII, 1948-49'.

44. See: Barisan Partai Sjarikat Islam Indonesia Bersiap!; PSII dari Tahun ke Tahun; Kongres PSII ke-29; Oral History with Harsono Tjokroaminoto, 1982. In ANRI, Koleksi Sejarah Lisan, 1982 \#60, tapes 10, 16, and 28.

45. For example, on his connections with Mohammad Natsir, see Audrey R. Kahin, 2012. Islam, Nationalism and Democracy: A Political Biography of Mohammad Natsir, Singapore: NUS Press, p. 47, n. 39.

46. Deliar Noer, 1987. Partai Islam di Pentas Nasional 1945-1965, Jakarta: Grafiti Pers, pp. 169-170.

47. Noer, 'Masjumi', pp. 105-107.

48. Anthony Reid, The Indonesian National Revolution, 1945-1950, Westport, CT: Greenwood Press, p. 99. For a personal account of a Muslim leader's growing distrust of Amir for religious and philosophical reasons, see Abu Hanifah, 1972. Tales of a Revolution, Sydney: Angus and Robertson, pp. 279-285.

49. For more on these points, see Fogg, 138ff.

50. Barisan Partai Sjarikat Islam Indonesia Bersiap!, pp. 1-3. 
51. According to Kahin, Nationalism and Revolution, p. 210, n. 6, S.M. Kartosuwirjo (later founder of Darul Islam) was appointed Second Vice-Minister of Defense, and Surowijono was offered Vice-Minister of Education; both turned the appointments down, in seeming solidarity with Masjumi.

52. Kahin, Nationalism and Revolution, p. 210. Kahin also counts H. Anwaruddin, the Vice-Minister of Religion and then Acting Minister of Religion, as a PSII appointment in this cabinet, but other sources, including Noer, Partai Islam di Pentas Nasional, pp. 170-171, see him as a subsequent rather than simultaneous appointment.

53. On the roles of the latter two, see Barisan Partai Sjarikat Islam Indonesia Bersiap!, 16 and 3 , respectively.

54. Interview with Tahir Azhary, Ciputat, January 17, 2010. Other local ulama were also active in leading or sponsoring Islamic militias against the Dutch, including Kyai Yahya in Muara Enim (see Maliyanti, 2002. Peranan Syeikh Kyai Yahya dalam Pengembangan Islam di Muara Enim (1881-1951), Skripsi S1, Fakultas Adab dan Humaniora, IAIN-Raden Fatah, Palembang; K.H. Zen Syukri (interview with K.H. Zen Syukri, Palembang, June 7, 2010.) A similar account was given by a local Islamic activist who was unaffiliated with major organizations: interview with Mochtar Effendy, Palembang, June 7, 2010.

55. See Fogg, 183ff.

56. Interview with Tahir Azhary, Ciputat, January 17, 2010.

57. Mona Abaza has recognized such trends in Rasjidi and Fathurrahman Kafrawi, his two predecessors; see Abaza, Mona, 1993. Changing Images of Three Generations of Azharites in Indonesia, ISEAS Occasional Papers, no. 88, Singapore: ISEAS, p. 15.

58. The President's proclamation making this change can be found in ANRI, Koleksi RA2 Secretariat Negara, 1945-1949, \#615.

59. The form for the Constituent Assembly claims that Ahmad Azhary was the head of Masjumi for South Sumatra starting in 1945, but this could easily be a sort of appropriation of that title backwards in time so as to fill out his credentials. See ANRI, Koleksi Konstituante RA9, \#10. On the other side, in an interview with Tahir Azhary, Ciputat, January 17, 2010, Tahir Azhary claimed that his father had attended the conference in Jogjakarta that founded the Masjumi as a political party, but he got the date of that conference wrong. Tahir Azhary was also unclear on the chronology of PSII's split from Masjumi, and knew nothing about his father's stance on the issue, suggesting that Ahmad Azhary did not make this a point of polemics around his family, at the very least. Although not absolute evidence, the lack of a strong impression on the son at least suggests that the actions of the father were not such a strong point of principle as to be a teaching point for his children, and so may not have been carefully planned.

60. This was explicitly included as an option in the resolution: "Atau di njatakan dengan resmi dengan melakukan timbang terima dan penjerahan masuk ke dalam MASJUMI, jaitu supaja MASJUMI mendjadi pemangkowaris jangsah dari Partai Sjarikat Islam Indonesia." Barisan Partai Sjarikat Islam Indonesia Bersiap! p. 3.

61. Among others who take a very negative tone towards the split of PSII in 1947, see Noer, Partai Islam di Pentas Nasional, especially pp. 76-77; Oral History with Sjafruddin Prawiranegara, 1979. Interviewed by Caniago, J.R, ANRI, Koleksi Sejarah Lisan SL1, \#6, tape 4; Oral History with Burhanuddin Harahap, 1980. Interviewed by Caniago, J.R., ANRI, Koleksi Sejarah Lisan SL1, \#1, tape 4.

62. Oral History with HarsonoTjokroaminoto, 1982. Interviewed by Surjohardjo, Wardiningsih, ANRI Koleksi Sejarah Lisan, 1982 \#60 tape 16.

63. Interview with Tahir Azhary, Ciputat, January 17, 2010. 
64. This is recorded in ANRI, Koleksi RA9 Konstituante, \#10, and Aboebakar, H., 2011 [1957]. Sejarah Hidup K.H. A. Wahid Hasjim, Mizan: Jakarta, pp. 455-456.

65. Interview with Tahir Azhary, Ciputat, January 17, 2010.

66. ANRI, Koleksi Konstituante RA9, \#10.

67. Noer, Partai Islam di Pentas Nasional, p. 63, n. 42

68. ANRI, Koleksi Konstituante RA9, \#10.

69. Yusril Ihza Mahendra, 1999. Modernisme dan Fundamentalisme dalam Politik Islam: Perbandingan Partai Masyumi (Indonesia) dan Partai Jama'at-i-Islami (Pakistan), Jakarta: Penerbitan Paramadina, p. 77, n. 53.

70. This is clear from the fact that he was not listed as a dissenting vote from the Islamic bloc. See Saifuddin Anshari, 1979. The Jakarta Charter of June 1945: The Struggle for an Islamic Constitution in Indonesia, Kuala Lumpur: Muslim Youth Movement of Malaysia, p. 69.

71. Pedoman Perdjuangan Masjumi, 1955. $2^{\text {nd }}$ edition, Jakarta: Pimpinan Partai Masjumi Bagian Keuangan, pp. 81-93.

72. Interview with Tahir Azhary, Ciputat, January 17, 2010.

73. On the dissolution of Masjumi, see Fogg, pp. 401-406.

74. Interview with Tahir Azhary, Ciputat, January 17, 2010.

75. Interview with Tahir Azhary, Ciputat, August 22, 2012. See also Muhammad, Tahir Azhary et al., 2012. Beberapa Aspek Hukum Tata Negara, Hukum Pidana, dan Hukum Islam: Menyambut 73 Tahun Prof. Dr. H. Muhammad Tahir Azhary, S.H., Akademisi, Praktisi dan Politisi, Jakarta: Kencana.

\section{Bibliography}

Archival Collections

Arsip Nasional Republik Indonesia, Koleksi Sekretariat Negara 1945-1949 RA2

Arsip Nasional Republik Indonesia, Koleksi Konstituante RA9

Arsip Nasional Republik Indonesia, Koleksi Sejarah Lisan SL1

George McTurnan Kahin Papers, \#14-27-3146, Division of Rare and Manuscript Collections, Cornell University.

\section{Author's Interviews}

Interview with Mochtar Effendy, Palembang, June 7, 2010.

Interview with Tahir Azhary, Ciputat, January 17, 2010.

Interview with Tahir Azhary, Ciputat, August 22, 2012.

Interview with K.H. Zen Syukri, Palembang, June 7, 2010. 


\section{Unpublished Sources and Theses}

Fogg, Kevin W., 2012. The Fate of Muslim Nationalism in Independent Indonesia, PhD. Dissertation, Yale University.

Ismail, 2004. Madrasah dan Sekolah Islam di Karesidenan Palembang: 1925-1942 (Sejarah Sosial Pendidikan Islam pada Masa Kolonial), Disertasi S3, UINSyarif Hidayatullah, Jakarta.

Maliyanti, 2002. Peranan Syeikh Kyai Yahya dalam Pengembangan Islam di Muara Enim (1881-1951). Skripsi S1, Fakultas Adab dan Humaniora, IAIN-Raden Fatah, Palembang.

Noer, Deliar, 1960. Masjumi: Its Organization, Ideology, and Political Role in Indonesia. MA Thesis, Cornell University.

Yusnaini, 1998. Sejarah Perkembangan Pondok Pesantren Al-Ittifaqiah Inderalaya Sumatera Selatan, Skripsi S1, Fakultas Adab dan Humaniora, IAIN-Raden Fatah, Palembang.

\section{Published Sources}

Abaza, Mona (1993). Changing Images of Three Generations of Azharites in Indonesia, ISEAS Occasional Papers, no. 88, Singapore: ISEAS.

Aboebakar, 2011 [1957]. Sejarah Hidup K.H. A. Wahid Hasjim, Mizan: Jakarta.

Abu Hanifah, 1972. Tales of a Revolution. Sydney: Angus and Robertson.

Amin, Abdul Azim, 1998. Syekh Muhammad Azhary bin Abdullah al-Palembany dan Usahanya dalam Menegakkan Ajaran Agama Islam di Palembang, Palembang: Pusat Penelitian IAIN Raden Fatah Palembang.

Anshari,Saifuddin, 1979. The Jakarta Charter of June 1945: The Struggle for an Islamic Constitution in Indonesia, Kuala Lumpur: Muslim Youth Movement of Malaysia, 1979.

Azhary, Muhammad Tahir, et al., 2012. Beberapa Aspek Hukum Tata Negara, Hukum Pidana, dan Hukum Islam: Menyambut 73 Tahun Prof. Dr. H. Muhammad Tahir Azhary, S.H., Akademisi, Praktisi dan Politisi, Jakarta: Kencana.

Azra, Azyumardi, \& Umam, Saiful (eds.), 1998. Menteri-Menteri Agama RI: Biografi Sosial-Politik, Jakarta: INIS, PPIM and Departemen Agama RI, 1998.

Benda, Harry J., 1958. The Crescent and the Rising Sun: Indonesian Islam under the Japanese Occupation, 1942-1945. The Hague: W. van Hoeve.

Elson, Robert E., 2009. 'Disunity, Distance, Disregard: The Political Failure of Islamism in Late Colonial Indonesia', Studia Islamika, vol 16 no. 1: pp1-50. 
Jafizham, Tengkoe, 1939. Studenten Indonesia di Mesir. Medan: Sinar Deli.

Kahin, Audrey R., 2012. Islam, Nationalism and Democracy: A Political Biography of Mohammad Natsir, Singapore: NUS Press.

1999. Rebellion to Integration: West Sumatra and the Indonesian Polity. Amsterdam: Amsterdam University Press.

Kahin, George McT., 1952. Nationalism and Revolution in Indonesia. Ithaca, NY: Cornell University Press.

Kongres P.S.I.I. ke-29: 20-27 Maret 1953 di Jakarta, 1953. Jakarta: Partai Sjarikat Islam Indonesia.

Laffan, Micahel Francis, 2003. Islamic Nationhood and Colonial Indonesia: The Umma below the Winds. New York: Routledge.

Mahendra, Yusril Ihza, 1999. Modernisme dan Fundamentalisme dalam Politik Islam: Perbandingan Partai Masyumi (Indonesia) dan Partai Jama'at-i-Islami (Pakistan), Jakarta: Penerbitan Paramadina.

Noer, Deliar, 1987. Partai Islam di Pentas Nasional 1945-1965, Jakarta: Grafiti Pers.

, 1973. The Modernist Muslim Movement in Indonesia, 1900-1942, Singapore: Oxford University Press.

Pedoman Perdjuangan Masjumi, 1955. $2^{\text {nd }}$ edition. Jakarta: Pimpinan Partai Masjumi Bagian Keuangan.

Peeters, Jeroen, 1997. Kaum Tuo-Kaum Mudo: Perubahan Religius di Palembang, 1821-1942, Jakarta: INIS.

PSII dari Tahun ke Tahun, [1952]. [Jakarta?]: Departemen Penerangan dan Propaganda PSII.

Putjuk Pimpinan Partai Sjarikat Islam Indonesia, Bagian Penjiaran, [1948?]. Barisan Partai Sjarikat Islam Indonesia Bersiap!: Sedjarah Pembangunan P.S.I.I. Kembali. [Jogjakarta?]: Partai Sjarikat Islam Indonesia.

Reid, Anthony, 1986. The Indonesian National Revolution, 1945-1950, Westport, CT: Greenwood Press.

Roff, William R., 1970. 'Indonesian and Malay Students in Cairo in the 1920s', in Indonesia vol. 9: pp73-87.

Schacht, J., 2012. 'Muhammad 'Abduh', in Encyclopedia of Islam, second edition, Leiden: Brill Online.

Kevin W. Fogg, Oxford Centre for Islamic Studies. 


\section{Guidelines}

\section{Submission of Articles}

tudia Islamika, published three times a year since 1994, is a bilingual journal (English and Arabic) that specializes in Indonesian and Southeast Asian Islamic Studies. The aim is to provide readers with a better understanding of Indonesia and Southeast Asia's Muslim history and present developments through the publication of articles, research reports, and book reviews from Indonesian and international scholars alike.

Submission is open to both Indonesian and non-Indonesian writers. Articles will be assessed for publication by the journal's Board of Editors and will be peer-reviewed by a blind reviewer. Only previously unpublished work should be submitted. Articles should be between approximately 10,000-15,000 words. All submission must include a 150 -words abstract and 5 keywords.

Submitted papers must conform to the following guidelines: citation of references and bibliography use Harvard referencing system; references with detail and additional information could use footnotes or endnotes using MLA style; transliteration system for Arabic has to refer to Library of Congress (LC) guideline. All submission should be sent to studia.islamika@uinjkt.ac.id. 



\section{حقوق الطبعة محفوظة عنوان المر اسلة:}

Editorial Office: STUDIA ISLAMIKA, Gedung Pusat Pengkajian Islam dan Masyarakat (PPIM) UIN Jakarta, Jl. Kertamukti No. 5, Pisangan Barat, Cirendeu, Ciputat 15419, Jakarta, Indonesia. Phone: (62-21) 7423543, 7499272, Fax: (62-21) 7408633; E-mail: studia.islamika@uinjkt.ac.id Website: studia.ppim.or.id

$$
\begin{aligned}
& \text { قيمة الاشتر اك السنوي خار ج إندونيسيا: }
\end{aligned}
$$

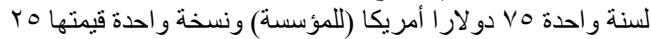

$$
\begin{aligned}
& \text { رقم الحساب: } \\
& \text { خارج إندونيسيا (دو لار أمريكا): }
\end{aligned}
$$

PPIM, Bank Mandiri KCP Tangerang Graha Karno's, Indonesia account No. 101-00-0514550-1 (USD).

$$
\text { داخل إندونيسيا (روبية): }
$$

PPIM, Bank Mandiri KCP Tangerang Graha Karno's, Indonesia

No Rek: 128-00-0105080-3 (Rp).

قيمة الاشتر الك السنوي داخل إندونيسيا:

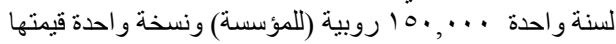

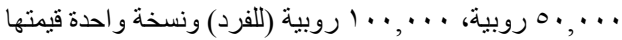

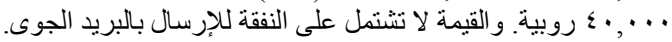

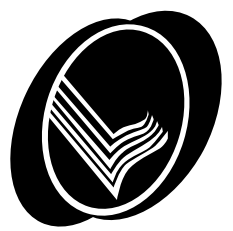




\section{سيّوديا إسلامياكيا مجلة إندونيسيا للار اسات الإسلامية

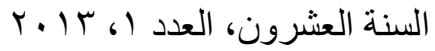

م. قريش شهاب (جامعة شريف هداية الله الإسلامية الحكومية جاكرتا)

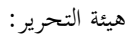

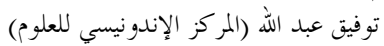

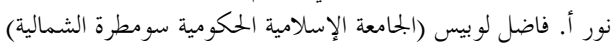
م.ش. ريكليف (جامعة أستراليا الحكومية كانبيرا) مارتين فان برونيسين (جامعة أتريخة)

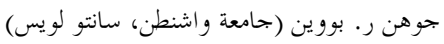

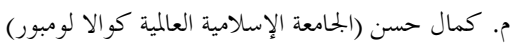
فر كنيا م. هو كير (جامعة أستر اليا الحكومية كانبيرا)

$$
\begin{aligned}
& \text { رئيس التحرير: } \\
& \text { أزيو ماردي أزرا } \\
& \text { المحررون: } \\
& \text { سيف الجحاني } \\
& \text { جمهاري } \\
& \text { جاجات برهان الدين } \\
& \text { عمان فتح الرحمن } \\
& \text { فؤ اد جبلي } \\
& \text { علي منحنف } \\
& \text { سيف الأمم } \\
& \text { إسماتو رافي } \\
& \text { دينا أفرينطي } \\
& \text { مساعد هيئة التحرير: } \\
& \text { تسطيريونو } \\
& \text { محمد نداء فضلان } \\
& \text { مر اجعة اللغة الإنحليزية: } \\
& \text { ميليسا كروش الإخليز : } \\
& \text { سيمون غلدمان } \\
& \text { مر اجعة اللغة العربية: } \\
& \text { نورصمد } \\
& \text { تصميم الغلاف: } \\
& \text { س. برنكا }
\end{aligned}
$$

ستوديا إسلاميكا (ISSN: 0215-0492) هي بحلة دورية يصدرها مركز البحوث الإسلامية

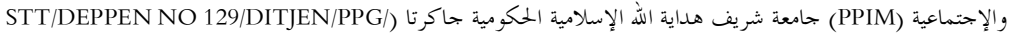

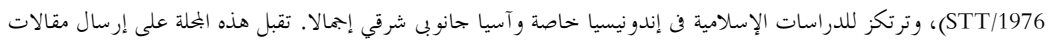

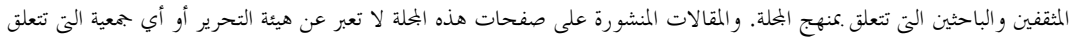

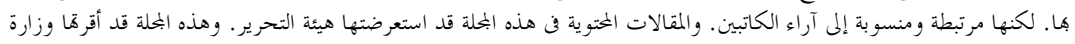





\section{لالقوديا السر|مسيا}




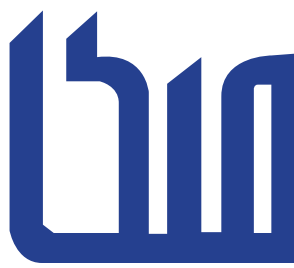

$\diamond$
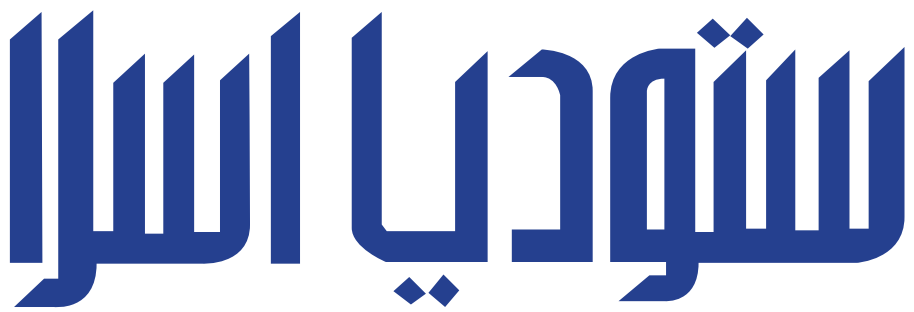

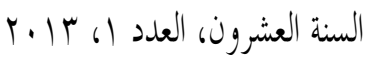

بحلة إندونيسية للدراسات الإسلامية

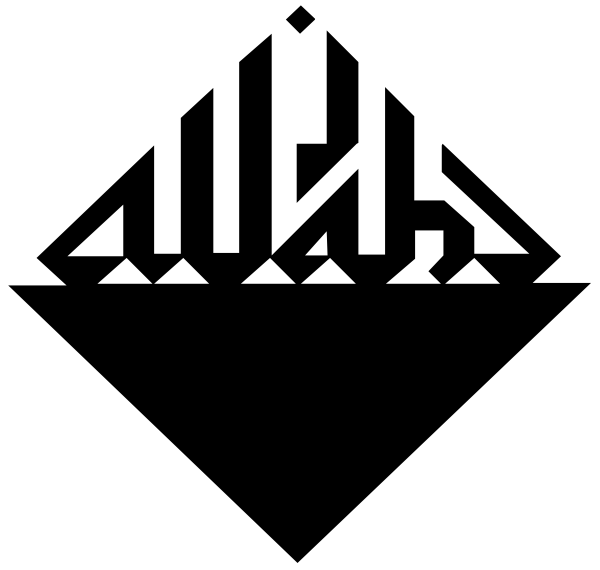

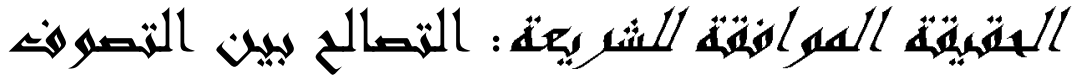

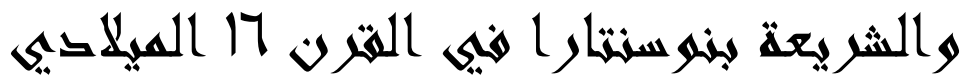
إئين سوريانينجسيه

جكول أحمال الأبزاهي الاسلامية

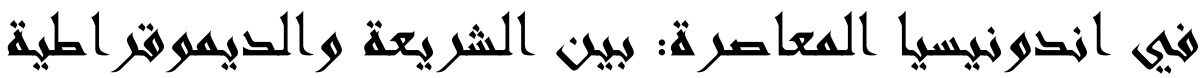
تاسمان 